\title{
CLINICAL IMPRESSIONS ON THE USE OF LARGACTIL AT SHAUGHNESSY HOSPITAL *
}

\author{
R. E. Simpson, M.D.**
}

THE term "artificial hibernation" first aroused our interest in Largactil. Huguenard (2) produces a state of "artifical hibernation," which has many of the characteristics of true hibernation, by means of a diffuse blockade of the whole autonomic nervous system, peripherally, at the synapses, and centrally. Thus the patient, his autonomic system unable to respond to injury, would be protected from shock produced by his own defence reactions.

This state is achieved by the use of the now well-known "Lytic cocktail," in which Huguenard combines a dozen or more "lytic" drugs. The Phenothiazine derivatives, Phenergan, Diparcol, and Largactil, however, are the main constituents of this cocktail. Their effects are essentially similar, but Huguenard considers Largactil as the most important single agent in his technique.

The chemical, physical, and pharmacological properties of Largactil have been most adequately described in the literature so only a brief résumé of its effects as related to anaesthesia will be considered.

Largactil has depressant action on the central nervous system which has not yet been completely defined. This depressant activity produces in many subjects a state of disinterestedness, sometimes described as a pharmacodynamic lobotomy. Reduced metabolism, hypothermia, absence of central vomiting, antagonism to central nervous system stimulants, and enhancement of the action of general anaesthetics, hypnotics, and analgesics are also reflections of this central depression.

Largactil not only produces muscle relaxation by a central action similar to that of myanesin, but also enhances the effect of Flaxedil, which acts peripherally.

This drug is an active adrenergic blocking agent. Parasympathetic functions, on the other hand, are inhibited only by larger doses of Largactil. Laboratory experiments show that, as well as exerting some protective action on haemorrhagic and traumatic shock, the compound has a definite stabilizing effect on adrenalin-induced cardiac arrhythmias.

Finally it should be noted that the drug is very irritant to tissues. Apparently this property depends on the concentration of the drug and not its low $\mathrm{pH}$ (5.3-5.6), and it is recommended that the drug be given deeply intramuscularly or diluted when given intravenously

Largactil has now been used in Shaughnessy Hospital in a total of 330 male patients.

\footnotetext{
'Presented at the Annual Meetıng, Canadian Anaesthetısts' Society, Vancouver, Britısh Columbia, June 14-15, 1954.

* Anaesthetıst, Shaughnessy Hospital, Department of Veterans Affarrs, Vancouver, B C
} 
Largactil Admenistiration-330 Cases

Total no.-Premedications (oral \& I.M.) 246

Total no.-I.V. in O.R.

$$
\frac{84}{330}
$$

Average age of patients

64.6 yrs.

Average weight of patients

These figures illustrate the operations and field covered:

TABLE I

\begin{tabular}{lcccc}
\hline & Oral & Intramuscular & Intravenous & Total \\
\cline { 2 - 5 } General anaesthetics & 30 & 66 & 44 & 140 \\
\hline Spinal & 80 & 55 & 30 & 165 \\
Blocks & 10 & 5 & 10 & $\frac{25}{330}$ \\
Total & 120 & -126 & 84 & 30 \\
\hline
\end{tabular}

General Surgery

171

Orthopaedics

58

Genito-urinary

50

Chest

Plastic

17

Neurosurgery

E.N.T.

\begin{tabular}{cr} 
& 171 \\
& 58 \\
& 50 \\
& 25 \\
& 17 \\
& 7 \\
Total & 2 \\
\hline
\end{tabular}

It was decided to combine Largactil with our usual techniques modifying them as little as possible. Usual premedication was not reduced and the clinical condition of the patient determined entirely the types and amounts of agents used.

The drug was first used intravenously during surgery, and later orally and intramuscularly in conjunction with normal premedication.

\section{Intravenous Use of Largactil}

Largactil was used intravenously in a total of 84 cases.' The drug was usually mixed with $500 \mathrm{cc}$. of Code 8 , at first in $100 \mathrm{mgm}$. doses but later $50 \mathrm{mgm}$. were considered sufficient. In many cases this method was not satisfactory, mainly because the prolonged action of the drug made the depth of anaesthesia difficult to assess. The patient would arrive in the post-anaesthetic recovery room depressed and considerable extra care was necessary, Respiratory obstruction was a common difficulty; patients, although easily aroused by shaking, would lapse into a flaccid semi-comatose state, the tongue blocking the airway.

In some cases, however, anaesthesia was smooth throughout, and the post- 
operative period uneventful. These patients, usually in the older age group, required small amounts of anaesthetic agents and seemed to make an unusually good recovery.

A number of patients under spinal anaesthesia, who exhibited nervousness, were given Largactil into the intravenous drip. Doses as small as $5 \mathrm{mgm}$. often produced a very satisfactory sedation for the length of the procedure. Although the B.P. usually remains unchanged, and no marked drops were noted, Largactıl should be used cautiously with spinal anaesthesia.

Other observations may be listed as follows:

1. Intravenous administration usually took 5 minutes to become effective, and maximum effects did not occur for 20 to 25 minutes.

2. The skn was warm and dry and the facies pale. Occasionally a rather marked pallor was observed.

3. Redness at the site of injection was noted in only four cases, and was transitory in nature. No cases of thrombophlebitıs were discovered during the post-operative follow-up.

4. Four patients under general anaesthesia had a Cheyne-Stokes pattern of breathing throughout part of the procedure Breathing, however, was usually deep and sometimes more rapid than usual. Rates as high as $30-40$ per minute have been observed-usually concomitant with light $\mathrm{N}_{2} \mathrm{O}$ anesthesia.

5. A marked fall in B P. occurred in 15 patients, all of whom were over 40 and most in the 60-80 age group. These cases were treated by posture, oxygen, and the intravenous administration of vasopressors in faurly large doses. B P. usually rose transiently and further doses were often required. Doses of 2 and even $4 \mathrm{mgm}$ of Neosynephrine sometimes failed to raise the B P to preoperative levels.

The following case is of interest.

Mr. A. R., a 49-year-old man in good physical health with a diagnosis of cortical atrophy.

The patient was booked for a pneumo-encephalogram. This was one of our early cases and chosen deliberately although it was expected that the erect posture might nót be well tolerated.

Normal B.P. was 105/90 He received the usual premedication of $100 \mathrm{mgm}$ of Demerol and $1 / 150$ of Hyoscine, and arrived in the operating room completely aware and only moderately well sedated Largactil $50 \mathrm{mgm}$. in $500 \mathrm{cc}$. of Code 8 was administered intravenously durng the hour immediately prior to operation. $25 \mathrm{mgm}$. of Demerol was given into this intravenous. The patient gradually became very sleepy with deep, slow respiration Pulse rose from 100 to 120 , and the B.P. dropped to $90 / 70$. In the sitting position the systolic pressure dropped to $40 \mathrm{~mm}$. of $\mathrm{Hg}$. and soon became imperceptiole, necessitating a rapid change to the Trendelenburg position. $30 \mathrm{mgm}$. of Me hedrine intravenously raised the systolic B.P. to 70 and an additional 30 raised it to 110 , but it dropped again to $60 \mathrm{~mm}$. in the upright position. The procedure was then completed with the patient receiving only oxygen by mask.

B.P. remained at $90 / 60 \mathrm{~m}$ the X-ray room where a further $30 \mathrm{mgm}$. of Methedrine produced no change. 
This patient was still semi-comatose when sent to the post-anaesthetic recovery room from X-ray. He dıd not retch or vomit and his skın was warm and dry in marked contrast to the usual sweating seen in these cases.

It was 5 P.M., eight hours after the anaesthetic, when this patient first became aware, although he responded to painful stimuli long before.

Four characteristics of Largactl are dramatically illustrated in this case:

1. The adrenergic blockade and its associated orthostatic hypotension. The sympathommetic effects of Methedrine were greatly reduced, if not blocked entirely.

2. The antagonism to analeptics, in this case Methedrine.

3. The enhancement or potentiation of opiates, e.g. Demerol.

4 The abolition of the nausea and vomiting commonly seen after pneumoencephalogram.

\section{Intramuscular and Oral Use of Largactil}

Largactl was used as an adjunct to premedication both orally and intramuscularly. Premedications were not reduced, Largactil mere y being used in place of Nembutal or Seconal $1 \frac{1}{2}$ hours preoperatively in the case of oral doses, or 1 hour preoperatively when the intramuscular route was used.

Doses varied from $12.5 \mathrm{mgm}$. to $125 \mathrm{mgm}$, no doses over $50 \mathrm{mgm}$ being given intramuscularly. Many of these patients came to surgery with excellent sedation, often disinterested in their surroundings and apparently asleep. They could be easily roused, however, and would respond intelligently to questions. No patient showed the hyper-excited or confused state sometimes.seen with barbiturates. Approximately half of our patients were madequately premedicated, some volunteering the information that their premedication for previous operations had been more satısfactory.

Fifteen patients received $100 \mathrm{mgm}$. or more of oral Largactil. Of these only three were adequately sedated One, on the other hand, was so deeply depressed that his operation was delayed for approximately two hours. This was the only patient in our series where premedication interfered with surgery. Four patients in this group were nauseated, and one actually retched. Seven patients were nervous and jumpy, four of these being extremely apprehensive.

As a whole, intramuscular injections were more satisfactory. More patients were adequately sedated, and restlessness or nausea has not been recorded.

TABLE II

\begin{tabular}{|c|c|c|c|c|}
\hline & \multicolumn{2}{|c|}{ LARGACTIL 25 mgm I M } & \multicolumn{2}{|c|}{ CONTROLS } \\
\hline & Operative time & Blood loss & Operative time & Blood loss \\
\hline Lobectomies-13 cases & $2 \mathrm{hr} 30 \mathrm{~min}$ & $813 \mathrm{cc}$ & $2 \mathrm{hr} 50 \mathrm{~min}$ & $1250 \mathrm{cc}$ \\
\hline 1st stage thoracoplasties -4 cases & $1 \mathrm{hr} 30 \mathrm{mn}$ & $925 \mathrm{cc}$ & $1 \mathrm{hr} 30 \mathrm{~mm}$ & $850 \mathrm{cc}$ \\
\hline 2 nd stage thoracoplasties -4 cases & $1 \mathrm{hr}$ & $842 \mathrm{cc}$ & $1 \mathrm{hr} 15 \mathrm{~min}$ & $925 \mathrm{cc}$ \\
\hline Pneumonectomies-1 case & $2 \mathrm{hr} 30 \mathrm{~mm}$ & $1889 \mathrm{cc}$ & $2 \mathrm{hr} 25 \mathrm{~min}$ & $1485 \mathrm{cc}$ \\
\hline
\end{tabular}


Twenty-two chest patients in which blood loss was measured were given Largactil $25 \mathrm{mgm}$. in addition to their premedications. These were compared with 22 control patients. Average blood pressure levels in the Largactil group were approximately the same as in the controls.

No significant difference in blood loss is found in this small series.

In both the oral and intramuscular groups, eight patients showed moderately severe blood pressure drops which were unresponsive to ordinary doses of vasopressors. These patients were either given larger doses of vasopressors or carried status quo-if their condition warranted.

Largactil does appear to have some advantages:

1. Our general clinical impression was that the amounts of anaesthetic agents can be reduced. This was not true of all cases, but certain patients, particularly in the older age groups, have been maintained for long periods on a 3-1 mixture of $\mathrm{N}_{2} \mathrm{O}-\mathrm{O}_{2}$ after Largactil premedication and small doses of Pentothal and Curare for induction.

2. It was hoped to show a decrease in the amount of postoperative narcotics used. This was the initial impression, but after more critical analyses, no significant reduction was noted.

3. Largactil appears to be a powerful anti-emetic. However, owing to the low incidence of postoperative vomiting in this hospital, and the limited number of cases studied, we have had little experience with Largactil in this respect.

4. The operative and postoperative courses are often unusually smooth, especially in the aged.

5. Largactil has proved of some use in sedating the postoperative excitement such as that seen after cyclopropane anaesthesia.

Its disadvantages, however, appear to outweigh the advantages:

1. The drug is very irritant and must be diluted for use intravenously, and injected deeply intramuscularly.

2. A marked adrenergic blockade is sometimes produced. Fairly severe falls in blood pressure were encountered which were often completely refractory to ordinary doses of vasopressors.

3. The awakening period was prolonged. Some patents remained semicomatose for several hours making care in the recovery room mandatory.

4. The myanesin-like action of Largactil was noted in the recovery room also. The patient appears flaccid with general loss of muscle tone, and the chin must be held to maintain an airway. These patients are usually easily roused, but when left will lapse into sleep and become obstructed.

5. Perhaps Largactil's greatest disadvantage is its unpredictability. Small doses have produced fairly severe depression in some cases, while large doses often appear to have little effect. We were completely unable to predict what any given dose would do to any given patient.

6. Finally, it was felt that equally good anaesthesia can be achieved with our usual combined or balanced techniques. The drugs used, i.e., Pentothal, Demerol, Procaine, Curare, etc. are more predictable and patients rouse more quickly post-operatively. 


\section{Largactil in Combination}

In the search for a better method of using Largactil, it was decided to try a technique suggested by Baxter, Bolster, and McKecknie (2) of Invernèss. They use the three Phenothiazine derivatives together, i.e.; Largactil, Diparcol, and Phenergan. Phenergan is active antihistaminic and has definite hypnotic properties. Diparcol, a drug used in Parkinson's disease, is noted mainly for its parasympathetic blocking action, and its relief of muscle spasm. Like Phenergan and Largactil, it has a definite hypnotic effect. The chemical formulas of these three drugs show how closely they are related (Figure 1).

\section{FIGURE 1}

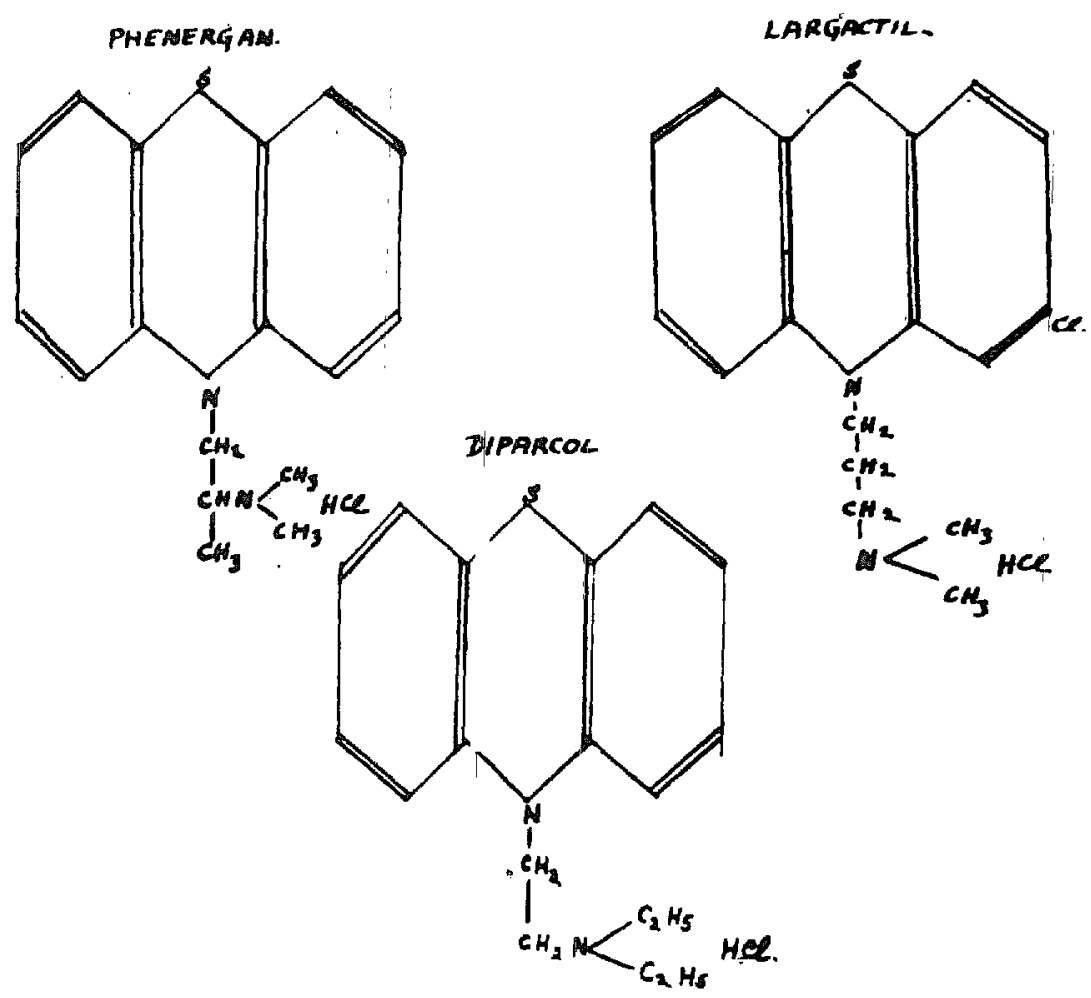

Their technique is as follows: The usual h.s. sedative is given. One hour preoperatively Phenergan $50 \mathrm{mgm}$., Demerol $100 \mathrm{mgm}$., and Atropine 1/100. are injected intramuscularly. The patient arrives in the operating room well sedated and fifteen minutes peroperatively a mixture of Diparcol $250 \mathrm{mgm}$., Demerol $100 \mathrm{mgm}$., and Largactil $50 \mathrm{mgm}$. in $20 \mathrm{cc}$. of distilled water is injected intravenously over five minutes. The patient goes gradually and pleasantly to sleep and the full effect is observed in about 15 minutes, when further anaesthesia, if needed, is commenced. This "Potentiating solution" as the authors call it, has been used at Shaughnessy Hospital in a short series of cases-fifteen in number.

Total number of cases receiving Potentiating solution-15

Average age of patient-59.7 (30-85) years.

Average weight $-143 \mathrm{lb}$.

Average duration of operation-1 hr, $40 \mathrm{~min}$. 
Type of operation: Gastrectomy 1

Laparotomy 1

Colostomy 1

Lumbar sympathectomy $\quad 4$

Left inguinal hernıa 1

Nephrectomy 2

Smith-Petersen Nar 1

Caldwell-Luc 1

Plastic graft to thigh 1

Burn dressing and skin graft 1

Arteriogram 1

Total $\quad 15$

Seven of the 15 patients required no supplemental anaesthetic agent other than $\mathrm{N}_{2} \mathrm{O}-\mathrm{O}_{2}$, but of these seven, four required small doses of Flaxedil either for intubation or for relaxation durng the course of surgery. The remaining eight patients required the addition of Pentothal in doses varying from 75 to $200 \mathrm{mgm}$., which was the largest dose given Two cases required small amounts of cyclopropane as well.

All patients were easily intubated, eleven with only a previous 10 per cent cocaine spray to the vocal cords. The remaining four required a relaxant before the endotracheal tube was passed, but Pentothal was not necessary.

Three patients did not require the enture $20 \mathrm{cc}$. of potentrating solution, one received half, while the other two were given three-quarters of the contents of the syringe.

When the mixture is injected it should be done slowly into a large vein through a small needle. Quick injection or the use of small superficial veins will sometimes produce a marked local reaction characterized by redness and oedema around the veins. One particular patient showed a rather alarming reaction but this process subsided in 48 hours with no further symptoms.

After approximately half of the solution has been given, the patient begins to lose consciousness. An elevation in pulse rate of $10-20$ points was noted and the B.P. showed a slight drop which soon returned to normal The maximum effect comes on approximately 15 minutes after the injection has been completed when the patients were intubated and surgery begun. Many patients showed a rather marked pallor about the face, appearing as if in shock, but in all cases the skin was warm and dry and the pulse and blood pressure stable.

Breathing was quiet and effortless-remarkably so in one asthmatic patient.

On the three occasions in the series when marked blood pressure drops were noted, they occurred after surgery had been established. The drops corresponded with change in position in two cases, and with traction under light anaesthesia in the third.

All other cases in the series were considered smooth, uneventful anaesthetics.

None of the patients were conscious at the end of the operation and did not awake until 3-4 hours after injection of the mixture. Once, awake they remained in a rather somnolent state but were easily aroused, co-operative, and rational 
when questioned. Nursing care was considered easier and there was no nausea or vomiting. Rectal temperatures were taken every 15 minutes in the postanaesthetic recovery room and a typical chart shows a temperature of $96^{\circ}$ or $97^{\circ}$ rising slowly to normal over three hours.

When a group of fifteen control cases were compared with this series, it was noted that when the potentiating solution was used, sedation required during the 12 immediately postoperatıve hours was markedly reduced. This reduction was not apparent, however, during the following 36-hour period when approximately the same amount of sedation was required in both jroups.

The results of this study have been encouraging. It is possi jle that the combination of Largactil with Phenergan and Diparcol produces a more balanced autonomic blockade, some of the disadvantages of Largactil alone being eliminated in this manner

In spite of the small number of cases recorded, the results do seem to suggest the following conclusions about Largactil in combination with Phenergan and Diparcol:

1. The amount of anaesthetic agents required is reduced.

2. The patients require less postoperative sedation during the first 12 hours after surgery

Other favourable clinical impressions have been

1. The lack of nausea and vomiting.

2 The short recovery period after surgery

3. The apparent lack of shock in old, poor-risk patients.

We feel that this method deserves further investigation.

\section{SUMMARY}

Largactll has been used in Shaughnessy Hospital in a total of 330 cases. The drug was used intravenously during surgery, and orally and intramuscularly in conjunction with usual premedication. - $n$ general the intramuscular route was felt to be the most satisfactory.

Although Largactil did appear to have some advantages-such as reducing the amounts of anaesthetic agents required and promoting smooth operative and postoperative courses in the aged-it was felt that its disadvantages outweigh the advantages. These disadvantages may be listed as follows.

1 The drug is irritant to tissue.

2. A profound adrenergic blockade is sometimes produced with associated marked drop in blood pressure.

3 The awakening period was prolonged.

4. The greatest disadvantage of Largactıl was judged to be its unpredictability.

A technique suggested by Baxter, Bolster, and McKecknie was described where three phenothiazıne derivatives, Largactil, Diparcol, and Phenergan, were combined. Although only fifteen cases were reported, the patients required such small amounts of supplementary anaesthetic agents during the operation, and made such excellent postoperative recovery, that further investigation of this technique was considered important 
In conclusion I would like to give credit to Dr. W. M. Hall, Dr. D. E. MacKay, and Dr. E. Ritch whose help in the preparation of this paper was invaluable.

\section{RÉSUMÉ}

Le Largactil a été adminıstré à l'hôpital Shaughnessy dans 330 cas. Une injection intraveineuse de la drogue a été fatte pendart l'opération, oralement et par injection intramusculaure en conjonction avec la prémédication habituelle. En général on est d'avis que la voie intramusculaire donne les résultats les plus satisfaisants.

Quoique le Largactıl semblait présenter des avantages - comme celui de réduire les quantités d'anesthétrques requis, et d'encourager des progrès égaux pendant et aprés l'opération chez les âgés - l'opinion est que les-désavantages l'emportent sur les avantages. Ces désavantages peuvent être énumérés comme suit:

1. La drogue irrite les tissus

2. Un barrage adrénergique pussant se produit quelquefois avec une baisse marquée de la pression du sang.

3. La période de réveil est prolongée

4. Le plus grand désavantage du Largactil est que son action ne peut pas être prédite.

Une technique proposee par Baxter, Bolster et McKecknie a été décrite, où trois dérivatifs de la phénothiazine, le Largactil, le Diparcol et le Phenergan ont été combinés. Quoique 15 cas seulement aient été rapportés, les patients exigeaient des quantités supplémentaires si petites d'agents anesthétiques pendant l'opération, et ont effectué des rétablissements si excellents après l'opération, que l'on considère comme important une étude additionnelle de cette technique.

\section{REFERENCES}

I Huguenard, P Hibernation artificielle-nouvelles données utiles Anesth et analg 9240 (1952).

2 Baxter, $R$ W, Bolster, J A, McKecknie, $S$ Three Phenothiazine Derivatives in Anaesthesia Anaesthesia 979 (1954) 